\title{
Effectiveness of Corticoid Administration in Orthognathic Surgery for Edema and Neurosensorial Disturbance: A Systematic Literature Review
}

\author{
Valthierre Nunes de Lima, DDS, MSc, ${ }^{\star}$ Cleidiel Aparecido Arauj Lemos, DDS, MSc, PhD, $\dagger$ \\ Leonardo Perez Faverani, DDS, PhD, $\ddagger$ Joel Ferreira Santiago Júnior, DDS, PhD, $\S$ \\ and Eduardo Piza Pellizzer, DDS, PhD/|
}

\begin{abstract}
Purpose: The aim of this systematic review was to evaluate the effect of corticosteroid (CS) administration on edema and neural regeneration in orthognathic surgery.

Materials and Methods: A systematic literature search was conducted using the PubMed (Medline), Cochrane Library, and Scopus databases. The PICO approach was used, in which patients with skeletal dentofacial deformity composed the population; uni- or bimaxillary orthognathic surgery composed the intervention; administration versus no administration of CSs composed the comparison; and decrease in postoperative edema and neurosensory disorders composed the outcome. Thirty of 240 articles were selected and evaluated for their titles and abstracts in relation to the inclusion and exclusion criteria. After duplicate references were eliminated, 8 articles remained.
\end{abstract}

Results: Patients who used CSs had lower rates of edema. In fact, after 4 months, there were no remarkable edema rates. These results suggest that neurosensory disorders resolved after 3 months. In addition, in the early and late periods, administration of CSs did not influence the regression of neurosensory disorders.

Conclusions: Administering CSs in orthognathic surgery improved the regression of facial edema independent of the dosage used but did not influence neurosensory disorders.

(C) 2017 American Association of Oral and Maxillofacial Surgeons

J Oral Maxillofac Surg 75:1528.e1-1528.e8, 2017

Administration of corticosteroids (CSs) during orthognathic surgery is routine practice for quicker resolution of facial edema and provides the patient with greater postoperative comfort. ${ }^{1}$ The effects of CSs on the inflammatory cascade are beneficial because they decrease dilation of the blood vessels and, hence, decrease permeability. ${ }^{2}$ Another factor that decreases edema is the inhibition of membrane rupture induced by lysozymes, which decreases the local release of proteolytic enzymes and hyaluronidase. ${ }^{3}$ In addition, the
*Student, São Paulo State University, School of Dentistry, Araçatuba, São Paulo, Brazil.

$\dagger$ †tudent, São Paulo State University, School of Dentistry, Araçatuba, São Paulo, Brazil.

$\ddagger$ Associate Professor, São Paulo State University, School of Dentistry, Araçatuba, São Paulo, Brazil.

$\S$ Associate Professor, Sacred Heart University, School of Dentistry, Bauru, São Paulo, Brazil.

||Full Professor, São Paulo State University, School of Dentistry, Araçatuba, São Paulo, Brazil.
Conflict of Interest Disclosures: None of the authors have a relevant financial relationship(s) with a commercial interest.

Address correspondence and reprint requests to Dr de Lima: Rua Jose Bonifacio, 1193, CEP 16015-050, Aracatuba, SP, Brazil; e-mail: valthierre@hotmail.com

Received February 152017

Accepted March 202017

(C) 2017 American Association of Oral and Maxillofacial Surgeons

0278-2391/17/30357-9

http://dx.doi.org/10.1016/i.joms.2017.03.039 
administration of CSs is believed to promote the inhibition of prostaglandin synthesis, thus providing an analgesic effect. ${ }^{4}$

Nerve damage is the result of direct or indirect trauma to a nerve. Compression or trauma results in edema in surrounding tissues and the release of inflammatory mediators that temporarily irritate the nerves. Some researchers have suggested that CSs promote the healing of traumatized nerves. ${ }^{5}$

Like all drugs, CSs have side effects, such as adrenal suppression, delayed healing, and euphoria, which generate concern among professionals about the most appropriate use or dosage in surgery. Thus, it is necessary to investigate the effects of CSs on the decrease of edema and neurosensory disorders in the postoperative period of maxillofacial surgeries to establish a clinical consensus. ${ }^{6}$

\section{Materials and Methods}

\section{METHOD AND REGISTRY PROTOCOL}

This systematic review was conducted according to the Preferred Reporting Items for Systematic Reviews and Meta-Analyses (PRISMA) statement ${ }^{7}$ and models proposed in the literature. ${ }^{8,9}$ The methods for this systematic review were registered with Prospero (CRD 42016048473).

\section{SEARCH STRATEGY}

Articles published until 2016 were selected individually by 2 authors (V.N.L. and C.A.A.L.) using the PubMed (Medline), Scopus, and Cochrane Library databases.

The search was conducted using 1) ortbognathic surgery and glucocorticoids OR orthognathic surgery and edema OR orthognathic surgery and steroids OR orthognathic surgery and neurosensory disturbances and 2) osteotomy, sagittal split ramus and glucocorticoids OR osteotomy, sagittal split ramus and edema OR osteotomy, sagittal split ramus and steroids OR osteotomy, sagittal split ramus and neurosensory disturbances. The same authors also manually searched for articles published until 2016 in the International Journal of Oral and Maxillofacial Surgery, Journal of Oral and Maxillofacial Surgery, Journal of Cranio-Maxillo-Facial Surgery, and British Journal of Oral and Maxillofacial Surgery.

\section{STUDY SELECTION AND ELIGIBILITY CRITERIA}

The studies selected for this review met the criteria established by the PICO approach. This included patients with skeletal dentofacial deformity as the population; uni- or bimaxillary orthognathic surgery as the intervention; administration versus no administration of CSs as the comparison; and decrease in postoperative edema and neurosensory disorders as the outcome.

The eligibility criteria included articles in the English language, controlled clinical trials, and randomized clinical trials (RCTs) or prospective studies with at least 10 patients. The exclusion criteria included animal studies, case reports, reviews, meta-analyses, case series, and articles that did not present relevant data for the purpose of this study.

\section{QUALITY ASSESSMENT OF SELECTED STUDIES}

Studies were analyzed to identify the risk of bias in the results and conclusions. The methodologic quality of the studies was assessed according to their level of evidence as proposed by the National Council on Health and Medical Research's levels of evidence and notes for recommendations according to the type of research question. ${ }^{10}$ These assess the diagnostic accuracy, prognosis, etiology, and screening intervention of the studies. The hierarchy of studies was classified as levels I, II, III-1, III-2, III-3, and IV.

\section{DATA COLLECTION PROCESS}

Data were extracted from the selected articles by one of the authors (V.N.L.). The following data were identified in each article: the first author, study type, osteotomy type (uni- or bimaxillary), number of patients treated with CSs, number of patients without CS treatment, mean age, type of CS used, dose of CSs, method of administration, period of administration, edema evaluation, and sensorineural evaluation.

For analysis of neurosensory disorders, the authors selected articles that presented at least 1 of the following evaluation methods: light touch sensation, needle prick sensation, 2 static points of discrimination (Weber test), 2 moving points of discrimination (Dellon test), and subjective assessment. For the articles that presented all these methods, the test that presented the greatest sensitivity was used; for the articles that did not use all these tests, the test with the largest number of patients with sensory disorders was chosen.

\section{ADDITIONAL ANALYSIS}

The articles were selected by the authors (V.N.L. and C.A.A.L.) and inter-examiner $(\kappa)$ tests were performed to evaluate the titles and abstracts, in addition to a full reading for the interpretation of the article, resulting in $\kappa$ test agreement with $\kappa$ values equal to 0.90 (PubMed), 1.0 (Scopus), and 1.0 (Cochrane Library). Agreement was reached by consensus, with all differences discussed and resolved by a third author (E.P.P.). 


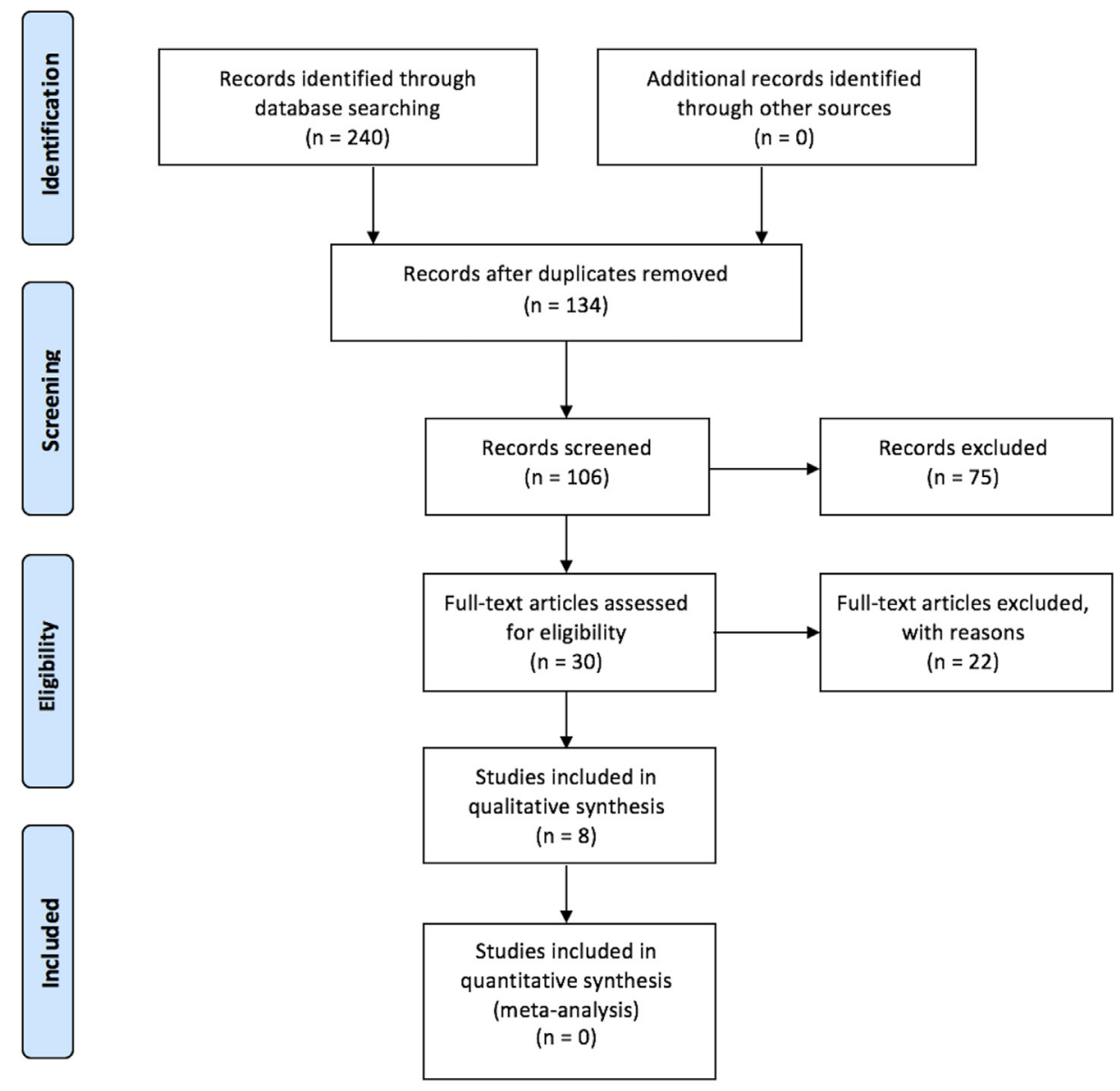

FIGURE 1. Flowchart of literature search strategy.

de Lima et al. Corticoid effects in Orthognathic Surgery. J Oral Maxillofac Surg 2017.

A comparative analysis of CS administration in the pre-, trans-, and postoperative periods of orthognathic surgery was conducted for the percentage of edema, presence of sensorineural disorders, type of CS administered, and dosage.

\section{Results}

The search of the 3 databases yielded 240 articles. Of these, 30 articles were selected and evaluated for their titles and abstracts. Then, the inclusion and exclusion criteria were applied, and any duplicate references were eliminated. Of the 30 articles, 22 were excluded because they did not state which CSs, dosages, or local treatments were used. An article published in 1994 was included because it contained relevant data for comparative analysis. ${ }^{11}$ Thus, 8 articles were selected for qualitative analysis, and none presented sufficient data for quantitative analysis (Fig 1)..$^{11-18}$

\section{EXPERIMENTAL DRAW}

All 8 articles were prospective studies and were published from 1994 to 2016 . The number of patients in each study ranged from 12 to 172 , and 5 studies had no control group. ${ }^{12-14,16,18}$ One study used betamethasone $^{17}$ and another used methylprednisolone $^{13}$ (Table 1).

\section{SELECTION OF PATIENTS}

A total of 315 patients with a mean age of 26.65 years underwent orthognathic surgery and were administered or not administered CS in the pre-, trans-, or postoperative period. Thus, 303 patients received CSs, including 172 who received methylprednisolone, 119 who received dexamethasone, and 24 who received betamethasone, with follow-ups ranging from 1 to 365 days (Tables 1 and 2).

\section{TYPE OF OSTEOTOMY}

All articles discriminated between the osteotomy types. Of these, 2 reported performing Le Fort I plus sagittal split ramus osteotomy, ${ }^{16,18} 2$ reported performing only sagittal split ramus osteotomy, ${ }^{11,17}$ and 4 reported performing Le Fort I with or without sagittal split ramus osteotomy ${ }^{12-15}$ (Table 1). 


\section{Table 1. SELECTED ARTICLES}

\begin{tabular}{|c|c|c|c|c|c|c|c|c|c|c|c|}
\hline Study & Study Type & $\begin{array}{l}\text { Type of } \\
\text { Blinding }\end{array}$ & $\begin{array}{l}\text { Level of } \\
\text { Evidence }\end{array}$ & Design Type & $\begin{array}{c}\text { Patients } \\
\text { Using Steroids }\end{array}$ & Controls & $\begin{array}{c}\text { Mean } \\
\text { Age }(\mathrm{yr})\end{array}$ & Original Steroids & $\begin{array}{c}\text { Original } \\
\text { Dose }(\mathrm{mg})\end{array}$ & $\begin{array}{l}\text { Method of } \\
\text { Delivery }\end{array}$ & Evaluation \\
\hline $\begin{array}{l}\text { Tozzi et al, } \\
2016^{18}\end{array}$ & $\begin{array}{l}\text { Randomized } \\
\text { clinical trial }\end{array}$ & $\begin{array}{l}\text { Double } \\
\text { blinded }\end{array}$ & II & Le Fort I + SSRO & 12 & 0 & 23.7 & Dexamethasone & $2,4,6$ & IV & Edema \\
\hline $\begin{array}{l}\text { Widar et al, } \\
2015^{17}\end{array}$ & $\begin{array}{l}\text { Randomized } \\
\text { clinical trial }\end{array}$ & $\begin{array}{l}\text { Double } \\
\text { blinded }\end{array}$ & III-1 & SSRO & 24 & 12 & 23.6 & Betamethasone & $16,8,4$ & IV and VO & $\begin{array}{l}\text { Edema and } \\
\text { nerve injury }\end{array}$ \\
\hline $\begin{array}{l}\text { Tozzi et al, } \\
2015^{16}\end{array}$ & $\begin{array}{l}\text { Randomized } \\
\text { clinical trial }\end{array}$ & $\begin{array}{l}\text { Double } \\
\text { blinded }\end{array}$ & II & Le Fort I + SSRO & 12 & 0 & 23.7 & Dexamethasone & $2,4,6$ & IV & Edema \\
\hline $\begin{array}{l}\text { Pourdanesh } \\
\text { et al, } 2014^{15}\end{array}$ & $\begin{array}{l}\text { Randomized } \\
\text { clinical trial }\end{array}$ & $\begin{array}{l}\text { Double } \\
\text { blinded }\end{array}$ & III-1 & $\begin{array}{l}\text { Le Fort I + SSRO } \\
\text { or SSRO }\end{array}$ & 18 & 18 & 26.1 & Dexamethasone & 8 & Local & Nerve injury \\
\hline $\begin{array}{l}\text { van der Vlis } \\
\text { et al, } 2014^{14}\end{array}$ & Prospective & - & III-3 & $\begin{array}{l}\text { Le Fort I + SSRO or } \\
\text { Le Fort I or SSRO }\end{array}$ & 49 & 0 & - & Dexamethasone & $10,8,4$ & IV & Edema \\
\hline $\begin{array}{l}\text { Mensink et al, } \\
2012^{13}\end{array}$ & Prospective & - & III-3 & $\begin{array}{l}\text { Le Fort I + SSRO or } \\
\text { SSRO }\end{array}$ & 172 & 0 & 29 & Methylprednisolone & $25,12.5$ & IV & Nerve injury \\
\hline Kau et al, $2007^{12}$ & Prospective & - & III-3 & $\begin{array}{l}\text { Le Fort I + SSRO or } \\
\text { Le Fort I or SSRO }\end{array}$ & 12 & 0 & 28.5 & Dexamethasone & 8 & IV & Edema \\
\hline $\begin{array}{l}\text { Weber and } \\
\quad \text { Griffin, } 1994^{11}\end{array}$ & $\begin{array}{l}\text { Randomized } \\
\text { clinical trial }\end{array}$ & $\begin{array}{l}\text { Double } \\
\text { blinded }\end{array}$ & III-1 & SSRO & 16 & 7 & 32 & Dexamethasone & 16,8 & IV & Edema \\
\hline
\end{tabular}

Abbreviations: IV, intravenously; SSRO, sagittal split ramus osteotomy; VO, oral administration.

de Lima et al. Corticoid effects in Orthognathic Surgery. J Oral Maxillofac Surg 2017. 


\section{Table 2. GROUPS AND DRUG DELIVERY}

\begin{tabular}{|c|c|c|c|c|c|c|c|c|}
\hline Study & Steroid Type & Preoperative & Transoperative & Postoperative & $\begin{array}{l}\text { Control } \\
\text { Group }\end{array}$ & Group 1 & Group 2 & Follow-Up \\
\hline $\begin{array}{l}\text { Tozzi et al, } \\
2016^{18}\end{array}$ & Dexamethasone & $6 \mathrm{mg}$ & $4 \mathrm{mg}$ & $4+2 \mathrm{mg}$ & No & $\begin{array}{l}6 \mathrm{mg} \text { IV } 30 \text { minutes before }+4 \mathrm{mg} \\
\text { no transoperative }+4 \mathrm{mg} 24 \mathrm{hr} \\
\text { postoperative }+2 \mathrm{mg} 48 \text { and } \\
72 \mathrm{hr} \text { after }\end{array}$ & - & 4 days \\
\hline $\begin{array}{l}\text { Widar et al, } \\
2015^{17}\end{array}$ & Betamethasone & 16 or $4 \mathrm{mg}$ & - & $4 \mathrm{mg}$ & Yes & $\begin{array}{l}4 \mathrm{mg} \mathrm{VO} 24 \mathrm{hr} \text { before }+8 \mathrm{mg} \mathrm{IV} \\
\text { preoperative }+4 \mathrm{mg} \text { VO } 24 \mathrm{hr} \\
\text { postoperative }\end{array}$ & $\begin{array}{l}16 \mathrm{mg} \text { IV } \\
\text { immediately } \\
\text { preoperative }\end{array}$ & $\begin{array}{l}1 \text { day to } \\
6 \text { mo }\end{array}$ \\
\hline $\begin{array}{l}\text { Tozzi et al, } \\
2015^{16}\end{array}$ & Dexamethasone & $6 \mathrm{mg}$ & $4 \mathrm{mg}$ & $4+2 \mathrm{mg}$ & No & $\begin{array}{l}6 \mathrm{mg} \text { IV } 30 \text { minutes before }+4 \mathrm{mg} \\
\text { no transoperative }+4 \mathrm{mg} 24 \mathrm{hr} \\
\text { postoperative }+2 \mathrm{mg} 48 \text { and } \\
72 \mathrm{hr} \text { after }\end{array}$ & - & $\begin{array}{l}1 \text { day to } \\
4 \text { mo }\end{array}$ \\
\hline $\begin{array}{l}\text { Pourdanesh } \\
\quad \text { et al, } 2014^{15}\end{array}$ & Dexamethasone & - & $8 \mathrm{mg}$ & - & Yes & $\begin{array}{l}2 \text { ampoules at } 4 \mathrm{mg} \text { applied over } \\
\text { nerve }\end{array}$ & - & $\begin{array}{c}1 \text { day to } \\
6 \text { mo }\end{array}$ \\
\hline $\begin{array}{l}\text { van der Vlis } \\
\text { et al, } 2014^{14}\end{array}$ & Dexamethasone & 一 & $10 \mathrm{mg}$ & $\begin{array}{l}10+8 \mathrm{mg} \text { for } \\
12-12 \mathrm{hr}+4 \mathrm{mg}\end{array}$ & No & $\begin{array}{l}10 \mathrm{mg} \text { transoperative }+10 \mathrm{mg} \\
\text { postoperative }+8 \mathrm{mg} \\
12-12 \mathrm{hr}+4 \mathrm{mg} \text { after }\end{array}$ & - & $\begin{array}{l}7 \text { day to } \\
12 \mathrm{mo}\end{array}$ \\
\hline $\begin{array}{l}\text { Mensink et al, } \\
2012^{13}\end{array}$ & Methylprednisolone & - & - & $\begin{array}{l}25 \mathrm{mg} \text { for } 12-12 \mathrm{hr}+ \\
12.5 \mathrm{mg} \text { for } \\
12-12 \mathrm{hr}+12.5 \mathrm{mg}\end{array}$ & No & $\begin{array}{l}25 \mathrm{mg} \text { for } 12-12 \mathrm{hr}+12.5 \mathrm{mg} \text { for } \\
12-12 \mathrm{hr}+12.5 \mathrm{mg} \\
\text { postoperative }\end{array}$ & - & $\begin{array}{l}1 \text { day to } \\
12 \mathrm{mo}\end{array}$ \\
\hline Kau et al, $2007^{12}$ & Dexamethasone & $8 \mathrm{mg}$ & - & $8 \mathrm{mg}$ & No & $\begin{array}{l}8 \mathrm{mg} \text { preoperative }+8 \mathrm{mg} \text { per } \\
24-24 \mathrm{hr}\end{array}$ & - & $\begin{array}{l}1 \text { day to } \\
6 \text { mo }\end{array}$ \\
\hline $\begin{array}{l}\text { Weber and } \\
\text { Griffin, } 1994^{11}\end{array}$ & Dexamethasone & $16 \mathrm{mg}$ & - & $8 \mathrm{mg}$ per $6-6 \mathrm{hr}$ & Yes & $16 \mathrm{mg}$ preoperative & $\begin{array}{l}16 \mathrm{mg} \\
\text { preoperative }+ \\
8 \mathrm{mg} \text { IV } 6-6 \mathrm{hr} \\
\text { postoperative }\end{array}$ & $\begin{array}{c}1 \text { day to } \\
3 \mathrm{~d}\end{array}$ \\
\hline
\end{tabular}

Abbreviations: IV, intravenously; VO, oral administration.

de Lima et al. Corticoid effects in Orthognathic Surgery. J Oral Maxillofac Surg 2017. 


\section{DEGREE OF EDEMA}

Six studies evaluated the degree of edema. ${ }^{11,12,14,16-18}$ However, 1 study performed a volumetric evaluation of edema regression ${ }^{14}$; for this reason, it was not included in Table 3, which presents the influence of CSs on this parameter. Different percentages were observed for the regression rate of edema. Lower rates were found in the groups that used CSs. After 4 months, there were no notable edema percentages (Table 3 ).

In a 1-day postoperative analysis of edema, the control group presented greater edema ${ }^{11,17}$ compared with the groups treated with CSs in the pre- and postoperative $^{11,12,16-18}$ and postoperative $^{11,17}$ periods. The maximum (control group) ${ }^{11}$ and minimum preoperative values $(13.3 \%)^{17}$ values were recorded. As presented in Figure 2, a more favorable result was observed for the test group independent of the drug administration periods.

\section{NEUROSENSORY DISORDER}

The authors evaluated sensorineural damage in 3 studies $^{13,15,17}$ that presented the number or percentage of patients with nerve damage after orthognathic surgery. Two studies ${ }^{15,17}$ presented control groups, and because they did not present homogeneity in the tests performed for the diagnosis, they were considered only if an independent disorder was present or absent at the applied examination (Table 4).

\section{SURGICAL TIME}

Although most articles reported surgical time, 2 articles described but did not report on the acquisition $\operatorname{method}^{11}$; that is, there was no uniformity among the studies for the measurement of time. The surgical time ranged from 104 to 186 minutes (Table 5).

\section{Discussion}

Based on the literature that was consulted, the level of evidence among the articles selected for this review was considered satisfactory, because at least 3 articles were prospective studies ${ }^{12-14}$ and the other 5 were RCTs. ${ }^{11,15-18}$ However, the 3 articles classified as prospective level III-3 ${ }^{12-14}$ did not include control groups to establish a comparison of the parameters proposed in the analyses related to edema and sensorineural disorders.

The RCTs were conducted as double-blinded (patient and surgeon) studies, which is extremely important in understanding the clinical responses in this type of experimental design. However, to compare groups of patients who received CSs with groups of patients who did not and to make correlations with the

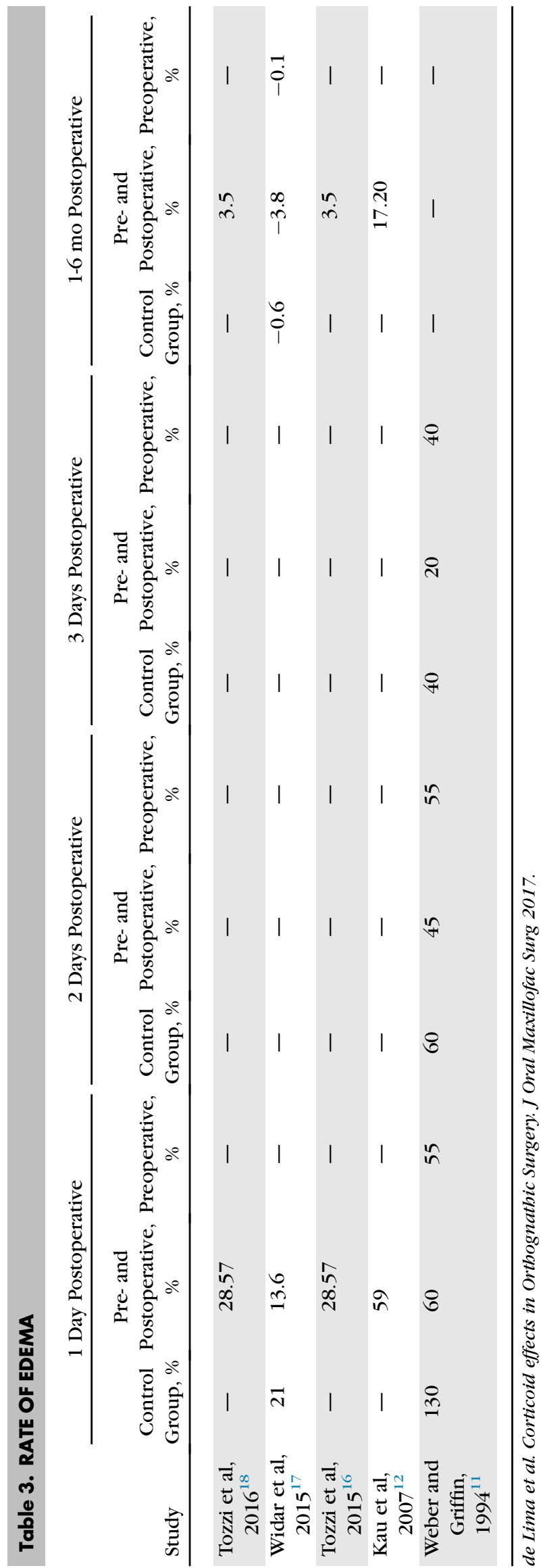




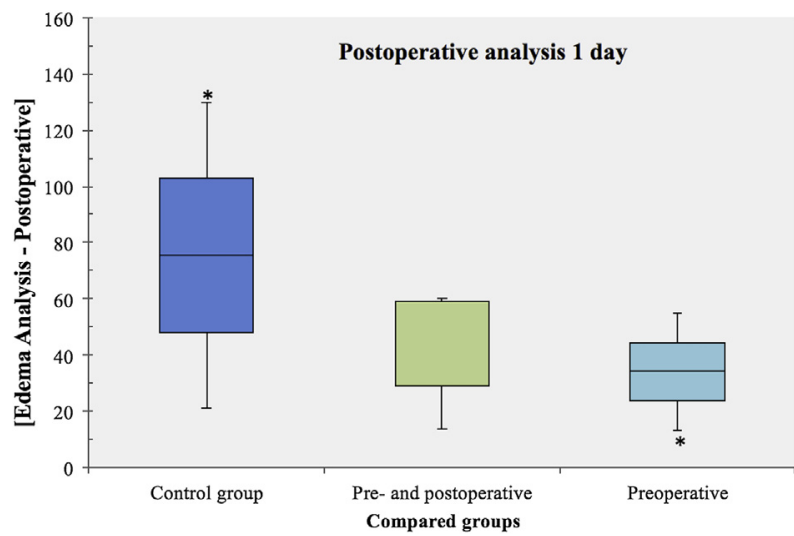

FIGURE 2. One-day postoperative analysis.

de Lima et al. Corticoid effects in Orthognathic Surgery. J Oral Maxillofac Surg 2017.

different degrees of edema or neurosensory disorders, another very important factor is the presence of control groups (no administration of CSs). In this context, only 3 articles $^{11,15,17}$ contained direct comparisons between CS and non-CS groups in the same study.

However, because of the lack of studies in the literature that analyze these parameters, the authors considered the control groups in only 2 articles. ${ }^{16,18}$ This was because the experimental groups presented another method or medication that interfered with edema, increasing the level of bias. These articles were considered to have a larger number of patients, which directly interferes with the evidence of the results.

In addition, in the analyses of the 2 studies performed by the same team with the same methodology, ${ }^{16,18}$ the means for the edema parameters of the 2 control groups presented equal values, which implies that they treated the same patients in these analyses. This limits the extrapolation of these results and the ability to compare them and establish a clinical consensus.

After the data were collected, the authors found that the administration of CSs at different dosages decreased the percentage of edema until the third postoperative day. These findings corroborate the work of Dan et $\mathrm{al}^{2}$ in a systematic review with meta-analysis of articles published from 1982 to 2006. In addition, even 10 years after the first evaluation, the present systematic review verifies that further clinical research is necessary to homogenize the data and to obtain data to perform a meta-analysis.

From these results, the authors observed that the percentages of edema were similar up to 48 hours postoperatively for the administration of CS alone during the preoperative period and the postoperative period, with a tendency to decrease in the group with preoperative and postoperative periods $^{11,12,16-18}$ (Table 3). At 72 hours after the procedure, the decrease in edema was similar between the control group and the preoperative use group (40\%); however, the association of CS in the postoperative period showed a greater decrease in edema during this period (20\%). ${ }^{11}$ It is important to point out that this article was included in this review because it contained relevant information on the subject being addressed and was not present in the previously published systematic review. ${ }^{2}$

Widar et $\mathrm{al}^{17}$ reported changes in the percentage of edema only on the first postoperative day; similarly, the comparison between the control group and the CS group, regardless of the dose administered, was statistically significant $(P=.017)$. However, in the groups that used CSs, the dosage did not influence the decrease of edema.

Van der Vlis et $\mathrm{al}^{14}$ performed a 3-dimensional analysis of postoperative edema in orthognathic surgeries with trans- and postoperative CS administration. They concluded that facial edema regressed during the first 3 weeks. These results were not tabulated in the present review because they did not present the initial value (time 0 ) and thus were considered as baseline in the last evaluation, which made the proposed analysis impossible.

\section{Table 4. NEUROSENSORY DISTURBANCES}

$\frac{\leq 1 \mathrm{mo}}{\text { No }} \frac{1-3 \text { mo }}{\text { Corticosteroids, Corticosteroids, Corticosteroids, Corticosteroids, Corticosteroids, Corticosteroids, }}$

\begin{tabular}{lcccccc} 
Study & $\%$ & $\%$ & $\%$ & $\%$ & $\%$ & $\%$ \\
\hline $\begin{array}{c}\text { Pourdanesh } \\
\text { et al, 2014 }\end{array}$ & 61.11 & 50 & 55.55 & 44.44 & 22.22 & - \\
$\begin{array}{c}\text { Mensink } \\
\text { et al, 2012 }\end{array}$ & - & - & - & - & 10.46 & \\
\hline
\end{tabular}


Table 5. TIME OF SURGERY IN MINUTES

Control Pre- and

Group Postoperative Preoperative

\begin{tabular}{lccc}
$\begin{array}{l}\text { Widar et al, } \\
2015^{17}\end{array}$ & 104 & 117 & 108 \\
$\begin{array}{c}\text { Weber and } \\
\text { Griffin, } 1994^{11}\end{array}$ & 186 & 175 & 164 \\
\hline
\end{tabular}

de Lima et al. Corticoid effects in Orthognathic Surgery. J Oral Maxillofac Surg 2017.

For the neurosensory disorders, 2 articles presented comparison data, ${ }^{13,15}$ but only 1 showed follow-up in periods of up to 1 month, 1 to 3 months, and more than 3 months. ${ }^{15}$ These results suggested that CSs did not meaningfully decrease nerve damage (Table 4). Mensink et $\mathrm{al}^{13}$ reported improvement in the percentage of nerve damage (10.46\%) in followup periods longer than 3 months compared with the findings of Pourdanesh et al. ${ }^{15}$ However, in the latter study, local application of the drug was performed differently from the other studies that applied the drug intravenously (Table 1 ).

The investigation by Widar et $\mathrm{al}^{17}$ for this parameter was based on the visual analog scale for pain and only reported the mean scores obtained from patients, without describing the sample size of each group, making it impossible to tabulate the data for this review. Widar et al used the applied test to show similarity among groups, regardless of the administration or dosage applied $(P>.30)$ on the first day and at 6 months postoperatively.

Because of the lack of standardization among tests applied to the diagnosis, only the presence or lack of the disorder was considered. Thus, more clinical and controlled studies need to be designed to obtain data for sensorineural disorders influenced or not by the action of CSs and analyzed by different sensorineural tests. By doing so, it will be possible to establish a clinical consensus on this issue.

In conclusion, the administration of CSs in orthognathic surgery helps in the regression of facial edema, independent of the dosage used, but it does not influence neurosensory disorders. However, more clinical and controlled studies are needed to establish a clinical consensus.

\section{References}

1. Chegini S, Dhariwal DK: Review of evidence for the use of steroids in orthognathic surgery. Br J Oral Maxillofac Surg 59:97, 2012

2. Dan AE, Thygesen TH, Pinholt EM: Corticosteroid administration in oral and orthognathic surgery: A systematic review of the literature and meta-analysis. J Oral Maxillofac Surg 68:2207, 2010

3. Melby J: Systemic corticosteroid therapy: Pharmacology and endocrinologic considerations. Ann Intern Med 81:505, 1974

4. Tam S, Hong SL, Levine L: Relationships among the steroids of anti-inflammatory properties and inhibition of prostaglandin production and arachidonic acid release by transformed mouse fibroblasts. J Pharmacol Exp Ther 203:162, 1977

5. Al-Bishri A, Rosenquist J, Sunzel B: On neurosensory disturbance after sagittal split osteotomy. J Oral Maxillofac Surg 62:1472, 2004

6. Assimes TL, Lessard ML: The use of perioperative corticosteroids in craniomaxillofacial surgery. Plast Reconstr Surg 103:313, 1999

7. Moher D, Liberati A, Tetzlaff J, et al: Preferred Reporting Items for Systematic Reviews and Meta-Analyses: The PRISMA statement. J Clin Epidemiol 62:1006, 2009

8. Silva LD, de Lima VN, Faverani LP, et al: Maxillary sinus lift surgery-With or without graft material? A systematic review. Int J Oral Maxillofac Surg 45:1570, 2016

9. Pires WR, Bonardi JP, Faverani LP, et al: Late mandibular fracture occurring in the postoperative period after third molar removal: Systematic review and analysis of 124 cases. Int J Oral Maxillofac Surg 46:46, 2017

10. Coleman K, Norris S, Weston A, et al: NHMRC additional levels of evidence and grades for recommendations for developers of guidelines. Available at: https://www.nhmrc.gov.au/_files_nhmrc/file/ guidelines/developers/nhmrc_levels_grades_evidence_120423. pdf, 2009 Published 2015

11. Weber CR, Griffin JM: Evaluation of dexamethasone for reducing postoperative edema and inflammatory response after orthognathic surgery. J Oral Maxillofac Surg 52:35, 1994

12. Kau CH, Cronin AJ, Richmond S: A three-dimensional evaluation of postoperative swelling following orthognathic surgery at 6 months. Plast Reconstr Surg 119:2192, 2007

13. Mensink G, Zweers A, Wolterbeek R, et al: Neurosensory disturbances one year after bilateral sagittal split osteotomy of the mandibula performed with separators: A multi-centre prospective study. J Craniomaxillofac Surg 40:763, 2012

14. van der Vlis M, Dentino KM, Vervloet B, et al: Postoperative swelling after orthognathic surgery: A prospective volumetric analysis. J Oral Maxillofac Surg 72:2241, 2014

15. Pourdanesh F, Khayampour A, Jamalian A: Therapeutic effects of local application of dexamethasone during bilateral sagittal split ramus osteotomy surgery. J Oral Maxillofac Surg 72:1391, 2014

16. Tozzi U, Santillo V, Tartaro GP, et al: A prospective, randomized, double-blind, placebo-controlled clinical trial comparing the efficacy of anti-edema drugs for edema control in orthognathic surgery using digitizer 3-D to measure facial swelling. J Maxillofac Oral Surg 14:386, 2015

17. Widar F, Kashani H, Alsén B, et al: The effects of steroids in preventing facial oedema, pain, and neurosensory disturbances after bilateral sagittal split osteotomy: A randomized controlled trial. Int J Oral Maxillofac Surg 44:252, 2015

18. Tozzi U, Santagata M, Sellitto A, et al: Influence of kinesiologic tape on post-operative swelling after orthognathic surgery. J Maxillofac Oral Surg 15:52, 2016 